\title{
Sperm preparation: state-of-the-art-physiological aspects and application of advanced sperm preparation methods
}

\author{
Ralf Henkel
}

For assisted reproduction technologies (ART), numerous techniques were developed to isolate spermatozoa capable of fertilizing oocytes. While early methodologies only focused on isolating viable, motile spermatozoa, with progress of ART, particularly intracytoplasmic sperm injection (ICSI), it became clear that these parameters are insufficient for the identification of the most suitable spermatozoon for fertilization. Conventional sperm preparation techniques, namely, swim-up, density gradient centrifugation and glass wool filtration, are not efficient enough to produce sperm populations free of DNA damage, because these techniques are not physiological and not modeled on the stringent sperm selection processes taking place in the female genital tract. These processes only allow one male germ cell out of tens of millions to fuse with the oocyte. Sites of sperm selection in the female genital tract are the cervix, uterus, uterotubal junction, oviduct, cumulus oophorus and the zona pellucida. Newer strategies of sperm preparation are founded on: (i) morphological assessment by means of 'motile sperm organelle morphological examination (MSOME)'; (ii) electrical charge; and (iii) molecular binding characteristics of the sperm cell. Whereas separation methods based on electrical charge take advantage of the sperm's adherence to a test tube surface or separate in an electrophoresis, molecular binding techniques use Annexin $\mathrm{V}$ or hyaluronic acid (HA) as substrates. Techniques in this category are magnet-activated cell sorting, Annexin V-activated glass wool filtration, flow cytometry and picked spermatozoa for ICSI (PICSI) from HA-coated dishes and HA-containing media. Future developments may include Raman microspectrometry, confocal light absorption and scattering spectroscopic microscopy and polarization microscopy. Asian Journal of Andrology (2012) 14, 260-269; doi:10.1038/aja.2011.133; published online 5 December 2011

Keywords: advanced sperm selection; biomimetics; conventional sperm selection; female genital tract; physiological sperm selection

\section{INTRODUCTION}

At ejaculation, tens of millions of spermatozoa are deposited by the human male into the upper part of the vagina near the cervical os from where they start their journey in a competitive race through the female genital tract to reach and fertilize the oocyte in the ampulla of the Fallopian tube. ${ }^{1,2}$ In the human, out of the total number of ejaculated spermatozoa, only about $10 \%$ will enter the cervix, $1 \%$ the uterus and $0.1 \%$ the Fallopian tube. Eventually, out of the $10^{2}-10^{3}$ spermatozoa that will reach the cumulus-oocyte complex, usually only one spermatozoon will fertilize the egg. ${ }^{1}$ Hence, it follows that an extremely stringent selection process of spermatozoa, which is essential for fertilization to produce healthy offspring, is occurring, in which the female genital tract is involved.

\section{Conventional sperm separation techniques}

With the advent of assisted reproduction technologies (ART), sperm separation strategies from seminal plasma were developed, which are mainly based on motility, and adhesion and filtration processes (reviewed in Refs. 3 and 4). While in the early years of ART, the focus was rather on obtaining motile spermatozoa, in later years, the focus shifted to the isolation of functional spermatozoa, a requirement dictated by the observations that functional sperm parameters are correlated with the results of fertilization in vitro (reviewed in Ref. 5).

Limitations of conventional sperm preparation techniques

By employing conventional sperm preparation strategies for ART, natural sperm selection processes taking place at various levels of the female genital tract (Figure 1) are bypassed to varying extents. In the case of intracytoplasmic sperm injection (ICSI), where a single spermatozoon is injected into the oocyte, all natural barriers for fertilization are bypassed and even sperm components that normally do not enter the female gamete are introduced. Thereby, oocyte activation and embryo development could possibly be impaired. ${ }^{6}$ Since spermatozoa with nuclear DNA damage are capable of fertilizing oocytes, ${ }^{7,8}$ this, depending on the severity of the damage, may cause recurrent pregnancy loss. ${ }^{9}$ Additionally, serious concerns regarding the health of the offspring were raised. ${ }^{10-12}$ On the other hand, embryos deriving from such germ cells can develop to full term. ${ }^{13}$ Thus, conventional sperm separation techniques show distinct limitations in that they do not necessarily select spermatozoa according to their functional competence or genetic quality as it is achieved in the female genital tract. 


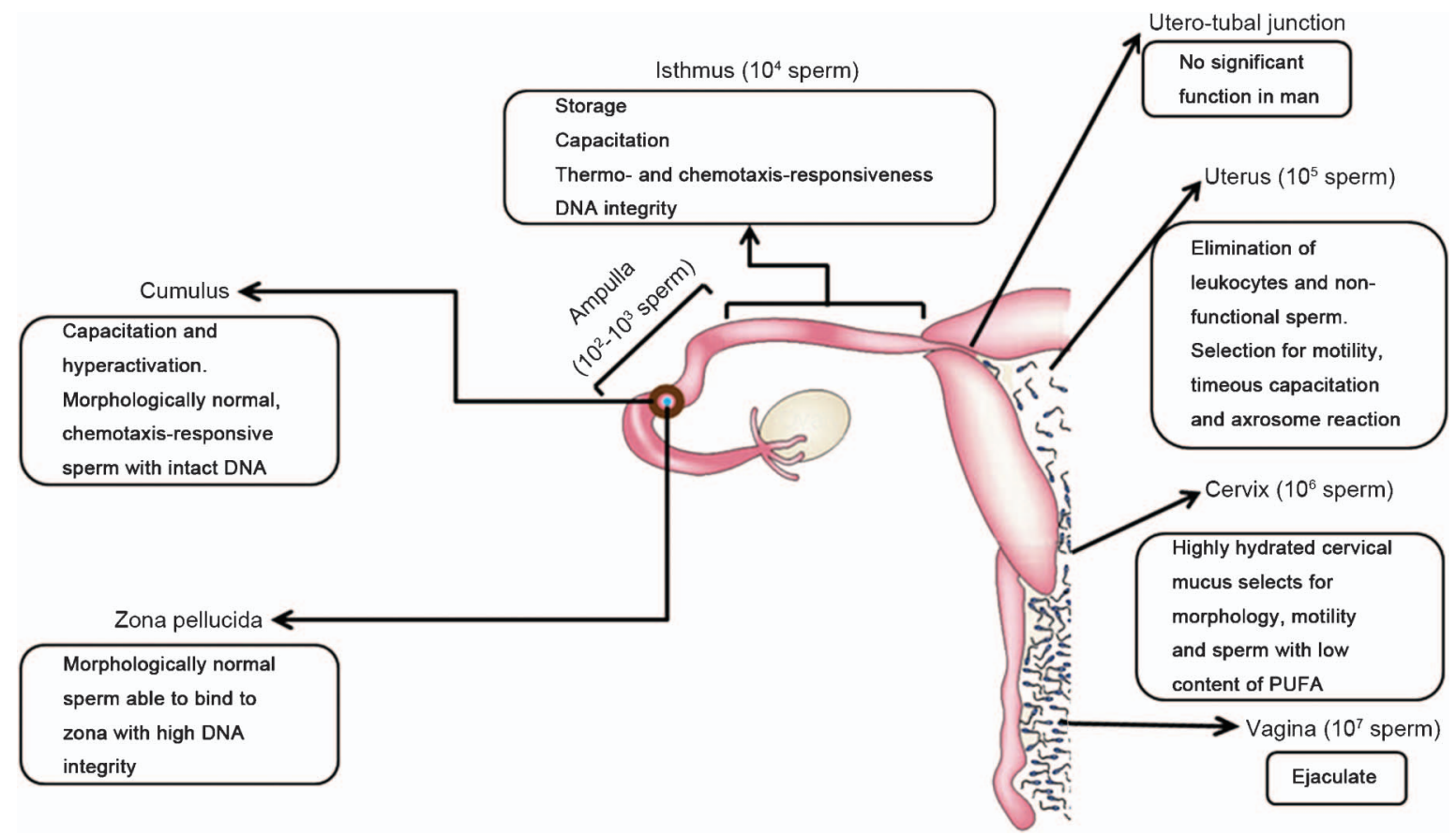

Figure 1 Sites of sperm selection in the human female. Estimated numbers of spermatozoa in the respective sections of the female genital tract are given in brackets. Soon after deposition in the vagina, spermatozoa move out of the seminal plasma and enter the highly hydrated cervical mucus where sperm selection for morphology and motility takes place. Spermatozoa that are selected here are characterized by a low plasma membrane content of PUFA. Subsequently, spermatozoa are transported through the uterus where male germ cells are selected for motility and timely capacitation. Dysfunctional spermatozoa are eliminated. After passing the uterotubal junction, which has, in contrast to numerous animal species, no significant function in man, spermatozoa enter the isthmus of the fallopian tube. In the isthmus, spermatozoa can be stored for up to 5 days. In the isthmus and the cumulus, spermatozoa are selected for capacitation, thermo- and chemotaxis-responsiveness and DNA integrity. Finally, after passing through the cumulus, spermatozoa bind to the zona pellucida where another morphological selection takes place. Moreover, male germ cells are further selected for zona-binding ability and DNA integrity (figure modified with permission from Ref. ${ }^{180}$ ). PUFA, polyunsaturated fatty acid.

\section{Considerations for advanced sperm separation methods}

In view of these concerns, scientists and clinicians are increasingly urged to improve sperm separation techniques in order to select the most functional spermatozoa for fertilization. Hereby, the emphasis is rather on the health of the progeny than on achieving pregnancy or increasing the success rates of ART. In vivo, the sperm selection process is entirely controlled by the female genital tract, which can be considered to execute some kind of 'sperm analysis' in order to identify and select the 'fittest' spermatozoon for fertilization and thereby ensure that the offspring receives the highest quality genetic material provided by a male germ cell. However, the question arises of how such selection for sperm DNA integrity is executed by the female organism. Apart from a selection based on sperm phenotype and functional characteristics, selection for genomic and molecular integrity appears to occur.

To achieve selection of spermatozoa based on these natural principles, scientists and clinicians need to understand the processes of sperm selection occurring in the female genital tract in order to mimic the chemical and physical mechanisms involved, ${ }^{14}$ i.e. the principles of sperm selection should be as close as possible to the natural selection processes in the female. Therefore, this paper is presented as an update on the current main sperm separation methods and their problems, as well as sperm selection in the female genital tract and advanced strategies of sperm preparation for ART based on new insights in the physiological mechanisms of sperm selection in vivo.

\section{SITES OF NATURAL SPERM SELECTION}

Sperm selection in the female genital tract is an extremely efficient and stringent process, which takes place at several levels, the (i) cervix, (ii) uterus, (iii) uterotubal junction (UTJ), (iv) oviduct, (v) cumulus oophorus and (vi) zona pellucida (Figure 1). The selection of functional spermatozoa at these different sites is achieved by a variety of mechanical, biochemical and biophysical mechanisms.

\section{Sperm selection in the cervical mucus}

In the human, after ejaculation, the semen forms a loose gel by coagulation. After about $30 \mathrm{~min}$ to $1 \mathrm{~h}$, this coagulum is enzymatically degraded by prostate-specific antigen ${ }^{15}$ and spermatozoa rapidly move out of the seminal plasma. Since seminal plasma not only protects the male germ cell and provides an energy resource, but also, if exposed to spermatozoa for too long time, decreases their function, the rapid leaving of spermatozoa from the seminal plasma is essential. ${ }^{16,17}$ They then enter the highly hydrated cervical mucus. ${ }^{18}$ The degree of hydration determines its penetrability for spermatozoa. ${ }^{19}$

The micro-architecture of this mucus depends on the stage of the menstrual cycle. While pre-ovulatory mucus contains linear, flexible and aligned fibers, ovulatory mucus is composed of floating globules of mucin aggregates, which explains the rapid transit of spermatozoa through the cervical mucus. ${ }^{20}$ Since spermatozoa are trapped and stored $^{21,22}$ in this mucus, some authors are in the opinion that in species like the human where the ejaculate is deposited in the vagina, the cervical mucus forms a sperm reservoir. ${ }^{23}$ On the other hand, there is also strong evidence for such sperm reservoir in the isthmus of the oviduct in various animal species.

The mechanisms by which sperm selection in the cervical mucus is taking place are thought to be due to both sperm motility and the ability of cervical mucus to select spermatozoa based on morphological 
criteria. ${ }^{24}$ However, other factors, including the mixing of the ejaculate with cervical mucus, as well as vaginal and uterine contractions, should be considered. ${ }^{25}$ Apparently, this morphological selection excludes spermatozoa bearing cytoplasmic droplets, ${ }^{26,27}$ which are regarded as abnormal features associated with damaged cellular function. ${ }^{28,29}$ However, recent observations revealed that cytoplasmic droplets may be the site of osmotic volume regulation and thus essential for human sperm function. ${ }^{30,31}$ A regulatory volume decrease of the male germ cell is linked to good motility ${ }^{30}$ and failure of the regulatory volume decrease will result in hindrance of mucus penetration. ${ }^{32}$ Thus, regulatory volume decrease might be an essential mechanism for spermatozoa to adapt their morphological appearance in order to fit through the mucin mesh of the cervical mucus. It might also be a function to attain or maintain progressive motility, which is necessary to pass through cervical mucus.

Chakroun-Feki et al. ${ }^{33}$ revealed that human cervical mucus selects a subpopulation of spermatozoa with cholesterol-rich plasma membranes and speculate that these spermatozoa are more mature. This assumption corroborates data by Ollero et al. ${ }^{34}$ who showed a decrease in the lipid content of Percoll-separated sperm. Thus, female selection of spermatozoa with a low content of polyunsaturated fatty acids would simply be a selection of good quality sperm, because excess polyunsaturated fatty acid triggers mitochondrial reactive oxygen species (ROS) production, ${ }^{35}$ which can cause functional damage to the sperm cell. ${ }^{36,37}$ However, the mechanism for this selection is currently unknown.

Uterus. Mechanisms involved in sperm selection within the uterus are being debated. A relatively new theory by Velando et al. ${ }^{38}$ considers leukocytes in cervical mucus and the uterus as being part of a selection mechanism, which functional spermatozoa have to overcome. These leukocytes produce elevated levels of ROS that would not only damage spermatozoa, but also trigger an increase in membrane permeability to ions essential for capacitation, chemotaxis and hyperactivated motility. ${ }^{39,40}$ These processes should not occur in the uterus.

Due to this oxidative stress caused by leukocytes, functional spermatozoa are compelled to leave this hostile environment in a short time. In fact, human spermatozoa have been detected in the Fallopian tubes 5-10 min after intercourse. ${ }^{41}$ This rapid movement of spermatozoa is assisted by myometrial contractions during the late follicular phase. $^{42}$ Once spermatozoa move out of the protective seminal plasma, they progressively lose the protection by scavengers for ROS and decapacitation factors such as spermine or glycodelin-S, ${ }^{43,44}$ which are abundant in seminal fluid. Considering that the uterus is part of the common mucosal immune system, spermatozoa have to leave or pass through these environments as soon as possible.

Utero-Tubal Junction. In many animal species, another major reduction in the number of spermatozoa progressing towards the oocyte occurs at the UTJ. Yet, compared with numerous animal species like cows or rabbits, where the entrance to the UTJ is characterized by a tortuous and very narrow lumen with large and small mucosal folds lined by epithelial cells with prominent cilia, in the human, sperm passage through the UTJ is rather simple (reviewed in Ref. 45). Therefore, the UTJ does not play a major role for sperm separation in man.

Oviductal isthmus. For those spermatozoa that reach the Fallopian tube, the environment changes from hostility in the vagina, cervix and uterus, where they attract leukocytes and need protection from maternal immune-recognition, to one that preserves and enhances sperm viability and motility, and stimulates capacitation. ${ }^{46}$
In pigs, cows or sheep, experiments have provided evidence that spermatozoa become trapped in the oviductal isthmus by binding to epithelial cells. ${ }^{47,48}$ Therefore, this part of the oviduct forms a sperm reservoir to ensure sperm survival until ovulation. However, man differs from these animal species in terms of the timing of coitus and the site of the deposition of the ejaculate. ${ }^{49}$ Therefore, the body of evidence is markedly weaker. However, a sperm reservoir has also been suggested in man as spermatozoa bind to epithelial cells of endosalpingeal explants. ${ }^{50}$ Due to the direct contact of the spermatozoa to oviductal cells, their functional lifespan is thought to be prolonged and capacitation delayed for about $24 \mathrm{~h}^{51}$ Once ovulation occurs, spermatozoa are released and capacitation and hyperactivation are triggered. This is thought to assist sperm detachment from the epithelium by providing the necessary force. ${ }^{52,53} \mathrm{~A}$ gradual release of spermatozoa from the reservoir helps prevent polyspermy by limiting the number of spermatozoa available at the fertilization site. ${ }^{54}$ On the other hand, Williams et al. ${ }^{1}$ did not find evidence for the human isthmus being a sperm reservoir.

In animal species, sperm binding to the oviductal epithelium appears to be mediated by fucose and galactose via acidic heparinbinding proteins in the acrosomal region. ${ }^{55,56}$ The epithelial receptors for the bovine seminal plasma proteins are Annexins containing fucose $^{57}$ and homologues of bovine seminal plasma proteins have been found in man as well as mice. ${ }^{58}$ To date, no consensus has been reached on how human sperm bind to the isthmic epithelium. However, there are indications that the adhesion sequence Arg-Gly-Asp (RGD) on sperm surface proteins might be involved. ${ }^{59}$

Very recent investigations in the bull by Gualtieri et al. ${ }^{60,61}$ revealed that the oxidation and reduction of sulphhydryl groups of sperm surface proteins reversibly modulate sperm adhesion to the oviductal epithelium as well as capacitation. If this kind of regulation would also be the case in the human, one has to consider that sperm binding to and release from the epithelium as well as triggering the events involved are dependent on a finely regulated redox status in the isthmus. Such changes in the redox status can occur quickly. If, however, limited amounts of ROS are produced in the oviduct, one must consider that these ROS (i) may modulate capacitation and hyperactivation $^{40}$ and (ii) might be detrimental, thus leading to the elimination of sperm. In fact, sperm attached to oviductal epithelial cells showed less abnormalities in the chromatin structure than those not attached. ${ }^{62}$

Up to now, two complementary mechanisms for sperm orientation in the oviduct have been revealed. A thermotactic mechanism is longranged and regulated through an intracellular inositol-triphosphate receptor $\mathrm{Ca}^{2+}$-canal, ${ }^{63}$ by which capacitated spermatozoa are released from the sperm storage site and guided towards the ampulla, where a $2{ }^{\circ} \mathrm{C}$ lower temperature prevails during ovulation. ${ }^{64,65}$ Whether thermotactic responsiveness of male germ cells plays a role in selective accumulation of spermatozoa remains to be demonstrated. Close to the oocyte, a second, short-range chemotaxis mechanism exists, which leads to recruitment of a population of capacitated spermatozoa. $^{66,67}$ Progesterone ${ }^{68}$ and nitric oxide ${ }^{69}$ may act as chemoattractants. Sanchez et al. ${ }^{70}$ showed that for the chemotactic response a critical physiological level of ROS is essential. Spermatozoa that fail to be guided by chemoattractants would then not proceed towards the oocyte. Thus, a responsiveness of the male germ cell to the chemoattractant could then be seen as an essential sperm function.

Cumulus oophorus. Once spermatozoa leave the isthmus, they travel into the ampulla and contact the cumulus oocyte complex, a process which is mediated by chemoattractants derived from follicular fluid, cumulus cells and the oocyte. ${ }^{71,72}$ Cumulus cells convert glycodelin-A 
and $-\mathrm{F}$ into cumulus-specific glycodelin- $\mathrm{C}^{73}$ and thereby remove the inhibitory activities of glycodelin-A and - $\mathrm{F}$ and enhance sperm-zona binding. ${ }^{74}$ The cumulus matrix has viscoelastic properties and can only be penetrated by hyperactivated spermatozoa, which is one requirement for penetration of the cumulus and zona pellucida. ${ }^{75,76}$ Additionally, cumulus-penetrated spermatozoa also show better morphology. ${ }^{77}$

A major component of the extracellular matrix of the cumulus is the linear polysaccharide hyaluronan (hyaluronic acid, HA), ${ }^{78}$ which is composed of alternating repeats of $D$-glucuronic and $N$-acetyl- $D$ glucosamine residues. ${ }^{79}$ Hyaluronan forms a complex with a glycodelin interacting protein, which retains and concentrates glycodelin- $\mathrm{C}$, which is essential for sperm-zona binding. ${ }^{80}$ In the human, it has been shown that during the final maturation steps of spermatogenesis, plasma membrane remodeling takes place that renders the male germ cell able to bind to hyaluronan and the zona pellucida. ${ }^{81,82}$ These data are supported by the presence of a HA receptor in human spermato$\mathrm{zoa}^{83}$ of which at least three hyaluronan binding proteins are involved in sperm maturation, acrosome reaction, motility, hyaluronidase activity and sperm-zona binding. ${ }^{84-86}$

Zona pellucida. The last barrier before sperm entry into the oocyte is the zona pellucida, which may be a final check-point for rejecting inadequate spermatozoa. Menkveld et al. ${ }^{87}$ and Liu and Baker ${ }^{88}$ found independently that the human zona pellucida has a selective capacity to bind morphologically normal spermatozoa. Thus, the zona pellucida represents the third place after cervical mucus and the cumulus where selection for morphological features takes place. It may also indicate the importance of normal sperm morphology as a parameter as it correlates very well with numerous sperm functions including acrosome reaction and normal DNA integrity. ${ }^{89,90}$ Patients with disordered zona-induced acrosome reaction show very low or no fertilization in in vitro fertilization (IVF) but good fertilization and pregnancy rates after ICSI. ${ }^{91}$

\section{ADVANCED STRATEGIES OF SPERM SELECTION}

Advanced strategies of sperm selection are defined as being based on sophisticated principles that employ physiological selection procedures. These principles are founded either on a more stringent assessment of sperm morphology, which is a sperm characteristic selected for at three different sites in the female (Figure 1), or on molecular characteristics of mature spermatozoa, which are associated with proper cellular function and genomic integrity. Currently, advanced selection procedures can be divided into three groups, on the basis of (i) sophisticated morphological assessment; (ii) electrical charge; and (iii) molecular binding. The latter two principles in part mimic female selection mechanisms.

\section{Selection based on morphology}

Normal sperm morphology evaluated after fixation on the basis of strict criteria $^{92}$ at $\times 1000$ magnification is regarded as a good predictor of fertilization success in vitro. ${ }^{93}$ For ICSI, however, the embryologist selects the most normal (least abnormal)-looking spermatozoon on the basis of light microscopy at magnifications of $\times 400$ in unfixed, unstained, wet sperm preparations. Success of assisted reproduction is also dependent on the ultramorphology of the spermatozoon that is taken for injection. Therefore, morphological discrimination by means of light microscopy is not good enough as subtle malformations, particularly DNA damage and chromosomal aberrations, ${ }^{94,95}$ cannot be detected and defective spermatozoa might be accepted for normal ICSI procedure. ${ }^{96,97}$
Ryu et al. ${ }^{98}$ highlighted the relationship between sperm morphology and genetic abnormalities by showing significantly higher frequencies of aneuploidy in infertile patients.

Motile sperm organelle morphological examination (MSOME). Since light microscopically invisible damage may be the reason that chromosomal or DNA damage in spermatozoa can be transferred to the progeny, ${ }^{99}$ a method that evaluates sperm morphology at higher, digital magnification $(\times 6300)$ using Nomarski interference contrast has been developed. ${ }^{100}$ With MSOME, the morphological status of the acrosome, post-acrosomal lamina, neck, mitochondria, flagellum and the sperm nucleus is examined. For the latter, the shape, as well as the presence and size of vacuoles, is observed. Since MSOME identifies objects undetectable by light microscopy, such as nuclear vacuoles, which are indicative of abnormal chromatin packaging, ${ }^{101}$ this method is much more stringent than the evaluation of sperm morphology according to strict criteria. ${ }^{102}$

MSOME is now included into ICSI protocols in an increasing number of centers for ART. The combination of MSOME and ICSI has been named intracytoplasmic morphologically selected sperm injection (IMSI). ${ }^{103}$ Compared with standard ICSI procedures, IMSI has been shown not only to increase fertilization rates, ${ }^{100}$ but also implantation and pregnancy rates. ${ }^{103,104}$ These initial results were confirmed in a recent meta-analysis. ${ }^{105}$ Yet, Balaban et al. ${ }^{106}$ rather restrict the beneficial effects of IMSI to selected male factor patients. The beneficial effects of IMSI also appear to be reflected in lower aneuploidy and miscarriage rates. ${ }^{105,107}$

However, whereas no differences were observed when comparing the quality of day 2 embryos from ICSI and IMSI, ${ }^{108}$ such differences were evident when blastocysts were examined. ${ }^{109}$ This difference between these two studies highlights early and late paternal effects on the embryo. Previously, it has been shown that spermatozoa with abnormal genetic material are able to fertilize oocytes, ${ }^{7}$ thereby posing the risk that such damaged genomes can be manifested in the germ line. ${ }^{110,111}$ Nevertheless, the oocyte has the ability to repair damages transferred to the oocyte by the spermatozoon. Whereas cytoplasmic defects can be repaired by the oocyte immediately after gamete fusion, sperm nuclear deficiencies will only be detected after the paternal genome is switched on at the eight-cell stage. ${ }^{112}$

Concerns have been raised about IMSI because it is expensive and takes with $1.5-5 \mathrm{~h}^{113}$ longer than ICSI. Since the normal ICSI procedure is performed at $37^{\circ} \mathrm{C}$, the extended exposure of spermatozoa to this temperature might pose a risk to the male germ cell. Peer et al. ${ }^{114}$ exposed human spermatozoa to different temperatures for extended times and found that sperm morphology deteriorated significantly after incubation for $2 \mathrm{~h}$ at $37^{\circ} \mathrm{C}$, which was not the case after incubation at $21^{\circ} \mathrm{C}$. Therefore, the authors recommended the performance of IMSI at $21^{\circ} \mathrm{C}$.

\section{Electrical charge}

During epididymal maturation, human spermatozoa acquire three forms of the highly sialylated and negatively charged, lipid-anchored gp20/CD52 glycopolypeptides ${ }^{115}$ via epididymosomes and prostasomes. ${ }^{116}$ The level of expression of this protein on spermatozoa appears to be positively correlated with the percentage of normal morphological forms in the same sperm cell as well as with the state of sperm capacitation and status of male fertility. ${ }^{17,118}$ Based on this negative electrical charge, it is possible to separate spermatozoa by means of the so-called (i) zeta potential and (ii) electrophoretic technique. 
Zeta potential. The electrical charge (from $-16 \mathrm{mV}$ to $-20 \mathrm{mV}$ ) of the sperm plasma membrane is called electrokinetic potential or 'zeta potential $^{119}$ and must not be confused with the membrane potential. While the latter is the electrical potential difference between the inside and outside of a cell membrane, the 'zeta potential' is the electrical potential at the slipping plane of a moved particle (here the sperm cell) in suspension away from the interface. Owing to their negative charge, spermatozoa adhere to glass surfaces when a culture medium is not supplemented with serum or albumin. Despite its own negative charge, albumin binds to both anions and kations, and therefore, neutralize this charge of the 'zeta potential'.

The zeta method is a simple method for the isolation of mature spermatozoa by allowing them to adhere to the surface of a positively charged test tube. ${ }^{120}$ This procedure can remove charged cells from a suspension so that the resulting population has better quality in terms of the ability of spermatozoa to undergo hyperactivation, normal DNA integrity, normal morphology and normal chromatin condensation. ${ }^{120,121}$ The method has been shown to select acrosomeand DNA-intact spermatozoa from populations obtained after cryopreservation $^{122}$ and increase fertilization rate after ICSI. ${ }^{123}$

Despite the low cost and the improved qualities of the selected population, the zeta method recovers only very low number of spermatozoa. ${ }^{120}$ Since X-bearing spermatozoa exhibit a higher net negative charge than Y-bearing spermatozoa, there might be a bias for the selection of X-bearing spermatozoa. ${ }^{119,124,125}$ Furthermore, since changes in the surface charge taking place as spermatozoa become capacitated are resulting in a decrease of sialylated surface proteins, ${ }^{117,126}$ the method has to be performed immediately after sperm separation from seminal plasma.

Electrophoresis. Based on the same principle, Ainsworth et al. ${ }^{127}$ developed an electrophoretic method to separate mature spermatozoa from immature, dysfunctional male germ cells and leukocytes, by using a microflow cell. With this method, functional spermatozoa penetrate through a polycarbonate membrane with $5 \mu \mathrm{m}$ pores, large enough to permit the passage of spermatozoa, but small enough to exclude larger cells including leukocytes that commonly contaminate ejaculates. Separation resulted in the isolation of highly motile spermatozoa of good morphology and DNA integrity. This method was also effective in isolating high quality spermatozoa from cryopreserved or testicular biopsy material at an average recovery rate of about $20 \%$ subsequently used for ICSI and resulting in normal delivery. ${ }^{128}$

Comparison of density-gradient centrifugation of spermatozoa using the ISolateTM medium with the electrophoretic method revealed comparable results of sperm recovery, motility and DNA damage. ${ }^{129}$ Recent investigations by Aitken et al. ${ }^{130}$ and Ainsworth et al. ${ }^{131}$ demonstrated that electrophoretically separated human spermatozoa are free of oxidative stress, capacitate and bind to zona pellucida normally. The technique does not result in a skewing of the ratio of X-and Y-bearing germ cells as suspected by others. ${ }^{120}$ These results might make the electrophoretic method useful for both IVF and ICSI. However, equipment is more expensive and not every ART unit may be able to afford the method.

\section{Molecular binding}

Numerous studies have shown that certain sperm surface molecules not only change during epididymal sperm maturation, but are also associated with normal sperm function. For identifying spermatozoa capable of fertilizing human oocytes, two methods base on molecular binding are currently used, sperm binding to annexin $\mathrm{V}$ and HA.
Annexin $\mathrm{V}$. Annexin $\mathrm{V}$ is a protein of about $35 \mathrm{kDa}^{132}$ that binds to the negatively charged phosphatidyl serine (PS), which is accumulated on the inner leaflet of the plasma membrane in viable cells. As an early sign of apoptosis, PS is translocated from the inner to the outer leaflet of the plasma membrane, ${ }^{133}$ indicating the sperm cell's inappropriateness for fertilization. Considering that PS can be detected with Annexin V on ejaculated, viable spermatozoa, Sakkas et al. ${ }^{134}$ called this 'abortive apoptosis'. On the other hand, PS also translocates during the processes of capacitation and acrosome reaction. ${ }^{135}$ Sperm translocation of PS to the outer-membrane is positively correlated with nuclear DNA damage, ${ }^{136}$ which reflects fertilization and pregnancy failure in assisted reproduction. ${ }^{7,137,138}$ In the light of this association, new methods to isolate spermatozoa that do not show PS on the outer membrane leaflet (non-apoptotic or Annexin V-negative) have been developed.

Magnetic beads. The magnet-activated (or magnetic-bead activated) cell sorting technique was initially developed by the Glander group in Leipzig, Germany. ${ }^{139,140}$ Annexin V-conjugated paramagnetic microbeads are used to eliminate apoptotic spermatozoa from a sperm suspension by allowing beads to bind to them followed by their subsequent removal by an external magnetic field. The non-apoptotic (Annexin V-negative) germ cells remain unlabelled and pass through the selection column. Magnet-activated cell sorting not only removes apoptotic spermatozoa efficiently from sperm suspensions, ${ }^{141}$ but also results in a fraction of spermatozoa with a significantly higher percentage with normal morphology, non-disturbed mitochondrial membrane potential, and less DNA damage. ${ }^{142,143}$

Clinical trials have shown higher cleavage and pregnancy rates after ICSI with magnet-activated cell sorting-selected spermatozoa than by density-gradient centrifugation in men with oligo-, astheno- and teratozoospermia. ${ }^{144}$ Recent reports ${ }^{145,146}$ of full-term pregnancies reveal this novel technique as safe and reliable for use in an assisted reproduction programme. Yet, these obvious advantages have to be balanced against the relatively high cost of the equipment, which might make this method unaffordable for smaller centers and less wealthy patients.

Annexin V-activated glass wool filtration. Glass wool filtration is a sperm selection method that has been known for more than three decades. Annexin-V-activated glass wool filtration is based on the principles of glass wool filtration (for review, see Ref. 3) and the affinity of Annexin V for PS. Scientists of the Glander group have chemically linked Annexin V to glass fibers. ${ }^{147}$ The method resulted in the selection of spermatozoa of high motility and normal mitochondrial membrane potential. Considering that this method is easy to perform and relatively inexpensive, it might gain some importance for isolating functional spermatozoa for IVF and ICSI. However, as it is still at an experimental stage, clinical data are still unavailable. Therefore, a definite recommendation for its use cannot be given yet.

Flow cytometric cell sorting. The flow cytometric cell sorting technique developed by Hoogendijk et al. ${ }^{148}$ utilizes fluorescentlylabeled Annexin V to mark PS-positive spermatozoa is highly effective in separating a subpopulation of spermatozoa with normal morphology. This technique is experimental and clinical data remain to be generated. However, as flow cytometers may not be affordable for many assisted reproduction units, particularly those in poor countries. 
HA. Mature human sperm membranes expose HA receptors. ${ }^{83}$ While early studies indicated stimulation of sperm motility ${ }^{149}$ and acrosome reaction ${ }^{150}$ by hyaluronan, recent reports have revealed that the percentage of sperm bound to HA reflects their maturational status and function. ${ }^{81}$ This observation can be used for fertility diagnosis as well as for the selection of functional spermatozoa for ICSI. ${ }^{151}$ Hyaluronan-bound spermatozoa exhibit lower percentages of chromosomal aneuploidies and DNA damage and show significantly improved general and nuclear morphology, as well as high embryo quality resulting from ICSI. ${ }^{152-155}$ Despite these positive results van den Berg et al. ${ }^{156}$ found no significant differences in fertilization rates and zygote scores by hyaluronan-bound and non-hyaluronan-bound spermatozoa in their controversially received ${ }^{157}$ study.

Although spermatozoa bound to hyaluronan had lower DNA damage and better chromatin condensation as compared to the controls, the HA-binding assay failed to predict fertilization, pregnancy and baby take-home rate after IVF and ICSI, thus sperm-hyaluronan binding had no predictive value in a clinical test. ${ }^{158,159}$ Petersen et al. ${ }^{160}$ found no differences in the percentages of normal spermatozoa in the hyaluronan-bound and non-hyaluronan-bound fractions. This failure of the hyaluronan binding test to predict fertility indicates only a limited role of isolated hyaluronan in sperm selection because both components of the cumulus, the extracellular matrix with its hyaluronan content, and the cumulus cells with their conversion of glycodelin-A and -F into glycodelin-C, contribute to the male germ cells' ability to penetrate the cumulus and modulate sperm functions. ${ }^{44,74,77}$ Yet, since implantation and pregnancy rates after ICSI did not improve when HA selected spermatozoa were used, ${ }^{153}$ the clinical relevance of sperm selection by means of their binding ability to hyaluronan is questionable. ${ }^{161}$ The reason for this failure of hyaluronan-separated spermatozoa to achieve higher impantation rates might be due to the nature of the method because other factors such as glycodelin-C are missing.

To date, two methods for HA binding are in use, namely, the picked spermatozoa for ICSI (PICSI) dish (hyaluronan-coated chamber) and a hyaluronan-containing medium. Both methods are ready to use systems that ate commercially available and have received official recognition for conformity with health and safety requirements in the EU and the United States. ${ }^{154}$

PICSI dish. Principally, the PICSI dish is a Petri dish that has spots of immobilized HA on it (MidAtlantic Diagnostic, Mount Laurel, NJ, USA). Washed or density gradient-prepared spermatozoa suspensions are placed on top of these spots of HA and incubated for $15 \mathrm{~min}$ at $37^{\circ} \mathrm{C}$. Subsequently, the freely moving spermatozoa are removed by gently rinsing the HA droplet and removing the non-bound sperm. Finally, the bound spermatozoa can be picked (P) with an ICSI pipette (hence PICSI). ${ }^{152}$

Hyaluronan-containing medium. The alternative to the PICSI dish is a viscous medium containing HA (Sperm Slow; MediCult, Jyllinge, Denmark). Here, a 5- $\mu$ l droplet of density gradient-prepared spermatozoa is connected with a pipette tip to a $5-\mu$ l droplet of Sperm Slow medium by dragging the suspension into contact and incubated for $15 \mathrm{~min}$ at $37^{\circ} \mathrm{C}$ under oil. Afterwards, spermatozoa bound to HA at the interface of the two droplets are selected with an ICSI pipette. ${ }^{154}$

Zona pellucida binding. Recently, zona pellucida-bound spermatozoa were used for ICSI. ${ }^{162-164}$ Although no difference in fertilization rate was observed compared to the control (normal ICSI), the use of zona-bound spermatozoa resulted in significantly higher quality of embryos, implantation and pregnancy rates suggesting that zona pellucida-bound spermatozoa are of superior quality. These data look promising. Yet, further results have to be reported before a definite recommendation in favor of this method can be made for routine sperm preparation.

\section{FUTURE DEVELOPMENT OF SPERM PREPARATION TECHNIQUES}

As sperm selection by a fertile female usually permits only those male germ cells that exhibit normal nuclear DNA integrity access to the oocyte, any artificial selection method mimicking the biological situation should monitor this essential parameter. However, all currently employed methods to determine DNA damage (TUNEL assay, SCSA, COMET assay, Halosperm assay, etc.) are invasive and therefore consumptive, meaning that the sperm cell that is being analyzed is used for the assay and consequently unavailable for fertilization. Nevertheless, in order to obtain healthy progeny, it is crucial that the female organism is able to select spermatozoa with undamaged DNA. However, currently, we can only speculate how this discrimination is achieved in the female reproductive tract. Since the female is unable to 'analyze' the quality of the sperm DNA directly, we can only reason that the stringent selection processes taking place at different levels of the sperm cell's way through the female genital tract are somehow associated with the DNA quality via other sperm parameters.

Clinical application of novel, more physiological sperm selection techniques demands that such techniques are non-invasive, safe, highly discriminative and relatively easy to perform. Moreover, it is imperative for any new method that sperm functions are maintained as much as possible and not compromised. These requirements might come at the cost of relatively expensive equipment or procedures. Among the cheaper methods is the utilization of cumulus cells in a Pasteur pipette $e^{165}$ or zonae pellucidae of immature oocytes ${ }^{162-164}$ as there are no differences in normal sperm morphology and DNA integrity of zona-bound sperm between mature and immature oocytes. ${ }^{89}$ Franken and Bastiaan ${ }^{165}$ showed that the percentages of cells with normal morphology, good quality chromatin condensation and tightly zona-bound spermatozoa were significantly higher in the cumulus-penetrated fraction of spermatozoa and speculate that this might be a possible means for the selection of functional spermatozoa for ART. However, for both approaches, the availability of cumuli and zonae pellucidae might be a problem, which would limit the applicability of the methods.

Recently developed techniques that are non-invasive and therefore have the potential to be used for isolation of potentially fertilizing spermatozoa are more sophisticated and more expensive than those that are currently used in ART and include Raman microspectrometry, confocal light absorption and scattering spectroscopic microscopy and polarization microscopy. At present, all of these are only in experimental stages and specific recommendations for routine application cannot be made.

\section{Raman microspectrometry}

Raman microspectrometry can provide detailed information about the efficiency of DNA packaging at the single-cell level by examining discrete laser scattering spectra, and can thus identify DNAcompromised cells. It has already been used successfully to discriminate, classify and diagnose malignancies and various tumors ${ }^{166-168}$ without having adverse effect on the cells analyzed. ${ }^{169}$ Huser and co-workers ${ }^{170}$ have suggested Raman microspectrometry to be a valuable tool in assessing sperm quality for assisted reproduction. 
Confocal light absorption and scattering spectroscopic microscopy This method is a combination of confocal microscopy and the principles of light-scattering spectroscopy. ${ }^{171}$ It provides excellent and highly specific images of subcellular structures at submicrometer levels beyond the diffraction limit of light. ${ }^{171,172}$ Itzkan et al. ${ }^{171}$ have been able to discriminate between apoptotic and non-apoptotic human bronchial epithelial cells.

\section{Polarization microscopy}

With the aim of obtaining sperm images closer in resolution to those obtained by electron microscopy, Baccetti ${ }^{173}$ has applied polarization microscopy to identify functional spermatozoa for use in ICSI. In this approach, the birefringence (double refraction) of light caused by the anisotropic properties of the compact texture of the sperm nucleus, acrosome and flagella permits the evaluation of the organelle structure of the male germ cell. Gianaroli et al. ${ }^{174,175}$ used the technique to distinguish acrosome-reacted from non-reacted spermatozoa. However, a report by Petersen et al. ${ }^{176}$ challenges this view. An association of sperm head birefringence with DNA damage is also questionable. ${ }^{176-178}$ Nevertheless, Gianaroli et al. ${ }^{179}$ report significantly higher implantation, clinical pregnancy and ongoing pregnancy rates.

\section{CONCLUSIONS}

Despite significant improvements in human sperm preparation methods during recent years, our knowledge about the physiological sperm selection processes in the female reproductive tract is still fragmentary, as can be noticed from contradictory reports of the effect of certain selection methods on sperm function and IVF/ICSI results. If the physiological processes could be mimicked, the number of spermatozoa used for insemination in intrauterine insemination or IVF would not only be drastically reduced, but the quality of spermatozoa that would be used for ICSI would increase. Additionally, success rates of assisted reproduction would improve as good quality spermatozoa bearing a genome of highest integrity would be selected.

Nevertheless, no simple solution to this dilemma is available, and certainly, the efforts in minimizing mutagenic or lethal effects of DNA damage will not come cheap, which might also be a problem, particularly in developing countries. Human reproductive scientists and clinicians are not only doing their utmost to assist infertile couples to fulfill their wish for a child, as the World Health Organization recognizes infertility as disease, but have also the duty to minimize the risks of ART for both the parents and progeny. Consequently, scientists have to understand the fertilization process better and search for the most 'physiological' methods for human sperm selection. Nevertheless, despite progress that has been made to select and identify the most suitable spermatozoa for human-assisted reproduction, most of the new techniques are large-scaled and therefore expensive. With respect to future developments, more confirming and expanded data remain to be seen as only preliminary results have been presented by individual groups.

\section{COMPETING FINANCIAL INTERESTS}

The author declares no competing financial interests.

1 Williams M, Hill CJ, Scudamore I, Dunphy B, Cooke ID et al. Sperm numbers and distribution within the human fallopian tube around ovulation. Hum Reprod 1993; 8: 2019-26.

2 Eisenbach M, Giojalas LC. Sperm guidance in mammals - an unpaved road to the egg. Nat Rev Mol Cell Biol 2006; 7: 276-85.
3 Henkel RR, Schill WB. Sperm preparation for ART. Reprod Biol Endocrinol 2003; 1: 108

4 Henkel R. Sperm processing for IVF. In: Nagy ZP, Varghese A, Agarwal A. Practical Manual of In Vitro Fertilization: Advanced Methods and Novel Devices. Springer; 2012. In press.

5 Franken DR, Henkel R. Sperm functional assays. In: Tandulwadkar S, Mittal B, eds. Optimizing IUI Results-A Guide to Gynecologists. New Delhi: Jaypee Brothers Medical Publishers (P) Ltd: 2010. pp155-67.

6 Morozumi K, Shikano T, Miyazaki S, Yanagimachi R. Simultaneous removal of sperm plasma membrane and acrosome before intracytoplasmic sperm injection improves oocyte activation/embryonic development. Proc Natl Acad Sci USA 2006; 103 : 17661-6.

7 Henkel R, Hajimohammad M, Stalf T, Hoogendijk C, Mehnert C et al. Influence of deoxyribonucleic acid damage on fertilization and pregnancy. Fertil Steril 2004; 81: 965-72.

8 Twigg JP, Irvine DS, Aitken RJ. Oxidative damage to DNA in human spermatozoa does not preclude pronucleus formation at intracytoplasmic sperm injection. Hum Reprod 1998; 13: 1864-71.

9 Carrell DT, Liu L, Peterson CM, Jones KP, Hatasaka HH et al. Sperm DNA fragmentation is increased in couples with unexplained recurrent pregnancy loss. Arch Androl 2003; 49: 49-55.

10 Aitken RJ, Krausz C. Oxidative stress, DNA damage and the Y chromosome. Reproduction 2001; 122: 497-506.

11 Hansen M, Kurinczuk JJ, Bower C, Webb S. The risk of major birth defects after intracytoplasmic sperm injection and in vitro fertilization. N Eng/ J Med 2002; 346: 725-30.

12 Wen SW, Leader A, White RR, Leveille MC, Wilkie V et al. A comprehensive assessment of outcomes in pregnancies conceived by in vitro fertilization/ intracytoplasmic sperm injection. Eur J Obstet Gynecol Reprod Biol 2010; 150: 160-5.

13 Gandini L, Lombardo F, Paoli D, Caruso F, Eleuteri P et al. Full-term pregnancies achieved with ICSI despite high levels of sperm chromatin damage. Hum Reprod 2004; 19: 1409-17.

14 Morrell JM, Rodriguez-Martinez H. Biomimetic techniques for improving sperm quality in animal breeding: a review. Open Androl J 2009; 1: 1-9.

15 Lilja H, Lundwall A. Molecular cloning of epididymal and seminal vesicular transcripts encoding a semenogelin-related protein. Proc Natl Acad Sci USA 1992; 89: 455963

16 Kanwar KC, Yanagimachi R, Lopata A. Effects of human seminal plasma on fertilizing capacity of human spermatozoa. Fertil Steril 1979; 31: 321-7.

17 Rogers BJ, Perreault SD, Bentwood BJ, McCarville C, Hale RW et al. Variability in the human-hamster in vitro assay for fertility evaluation. Fertil Steril 1983; 39: 204-11.

18 Katz DL, Slade DA, Nakajima ST. Analysis of preovulatory changes in cervical mucus hydration and sperm penetrability. Adv Contracep 1997; 13: 143-51.

19 Morales P, Roco M, Vigil P. Human cervical mucus: relationship between biochemical characteristics and ability to allow migration of spermatozoa. Hum Reprod 1993; 8: 78-83.

20 Brunelli R, Papi M, Arcovito G, Bompiani A, Castagnola M et al. Globular structure of human ovulatory cervical mucus. FASEB J 2007; 21: 3872-6.

21 Moghissi KS. Sperm migration through the human cervix. In:Insler V, Bettendorf G. The Uterine Cervix in Reproduction Stuttgart: Georg Thieme Publishers; 1977. pp146-65.

22 Harper MJK. Gamete and zygote transport. In:Knobil E, Neill JD. The Physiology of Reproduction. 2nd ed. New York: Raven Press Ltd; 1994. pp123-87.

23 Croxatto HB. Gamete transport. In:Adashi EY, Rock JA, Rosenwaks Z. Reproductive Endocrinology, Surgery and Technology Philadelphia, PA: Lippincott-Raven; 1996. pp385-402.

24 Pretorius E, Franken DR, de Wet J, Grobler S. Sperm selection capacity of cervical mucus. Arch Androl 1984; 12: 5-7.

25 Fox CA, Wolff HS, Baker JA. Measurement of intra-vaginal and intra-uterine pressures during human coitus by radio-telemetry. J Reprod Fertil 1970; 22: 243-51.

26 Mortimer D, Leslie EE, Kelly RW, Templeton AA. Morphological selection of human spermatozoa in vivo and in vitro. J Reprod Fertil 1982; 64: 391-9.

27 Fetic S, Yeung CH, Sonntag B, Nieschlag E, Cooper TG. Relationship of cytoplasmic droplets to motility, migration in mucus, and volume regulation of human spermatozoa. J Androl 2006; 27: 294-301.

28 Keating J, Grundy CE, Fivey PS, Elliott M, Robinson J. Investigation of the association between the presence of cytoplasmic residues on the human sperm midpiece and defective sperm function. J Reprod Fertil 1997; 110: 71-7.

29 Fischer MA, Willis J, Zini A. Human sperm DNA integrity: correlation with sperm cytoplasmic droplets. Urology 2003; 61: 207-11.

30 Yeung $\mathrm{CH}$, Cooper TG. Effects of the ion-channel blocker quinine on human sperm volume, kinematics and mucus penetration, and the involvement of potassium channels. Mol Hum Reprod 2001; 7: 819-28.

31 Cooper TG, Yeung CH, Fetic S, Sobhani A, Nieschlag E. Cytoplasmic droplets are normal structures of human sperm but are not well preserved by routine procedures for assessing sperm morphology. Hum Reprod 2004; 19: 2283-8.

32 Yeung $\mathrm{CH}$, Barfield JP, Cooper TG. Physiological volume regulation by spermatozoa. Mol Cell Endocrinol 2006; 250: 98-105.

33 Chakroun-Feki N, Therond P, Couturier M, Limea G, Legrand A et al. Human sperm lipid content is modified after migration into human cervical mucus. Mol Hum Reprod 2004; 10: 137-42. 
34 Ollero M, Powers RD, Alvarez JG. Variation of docosahexaenoic acid content in subsets of human spermatozoa at different stages of maturation: implications for sperm lipoperoxidative damage. Mol Reprod Dev 2000; 55: 326-34.

35 Cocco T, Di Paola M, Papa S, Larusso M. Arachidonic acid interaction with the mitochondrial electron transfer chain promotes reactive oxygen species generation. Free Radic Biol Med 1999; 27: 51-9.

36 Koppers AJ, Garg ML, Aitken RJ. Stimulation of mitochondrial reactive oxygen species production by unesterified, unsaturated fatty acids in defective human spermatozoa. Free Radic Biol Med 2010; 48: 112-9.

37 Henkel R. Leukocytes and oxidative stress: dilemma for sperm function and male fertility. Asian J Androl 2011; 13: 43-52.

38 Velando A, Torres R, Alonso-Alvarez C. Avoiding bad genes: oxidatively damaged DNA in germ line and mate choice. Bioessays 2008; 30: 1212-9.

39 Flesch FM, Gadella BM. Dynamics of the mammalian sperm plasma membrane in the process of fertilization. Biochim Biophys Acta 2000; 1469: 197-235.

40 de Lamirande E, Gagnon C. A positive role for the superoxide anion in triggering hyperactivation and capacitation of human spermatozoa. Int J Androl 1993; 16: $21-5$

41 Settlage DSF, Motoshima M, Tredway DR. Sperm transport from the external cervical os to the fallopian tubes in women: a time and quantitative study. Fertil Steril 1973 24: 655-61.

42 Kunz G, Beil D, Deininger H, Wildt L, Leyendecker G. The dynamics of rapid sperm transport through the female genital tract: evidence from vaginal sonography of uterine peristalsis and hysterosalpingoscintigraphy. Hum Reprod 1996; 11: 627-32.

$43 \mathrm{Ha} \mathrm{HC}$, Sirisoma NS, Kuppusamy P, Zweier JL, Woster PM et al. The natural polyamine spermine functions directly as a free radical scavenger. Proc Natl Acad Sci USA 1998; 95: 11140-5.

44 Yeung WS, Lee KF, Koistinen R, Koistinen H, Seppala M et al. Roles of glycodelin in modulating sperm function. Mol Cell Endocrinol 2006; 250: 149-56.

45 Suarez SS, Pacey AA. Sperm transport in the female reproductive tract. Hum Reprod Update 2006; 12: 23-37.

46 Kervancioglu ME, Djahanbakhch O, Aitken RJ. Epithelial cell co-culture and the induction of sperm capacitation. Fertil Steril 1990; 661: 1103-8.

47 Yanagimachi R, Chang MC. Sperm ascent through the oviduct of the hamster and rabbit in relation to the time of ovulation. J Reprod Fertil 1963; 6: 413-20.

48 Suarez SS. Sperm transport and motility in the mouse oviduct: observations in situ. Biol Reprod 1987; 36: 203-10.

49 Croxatto HB. Physiology of gamete and embryo transport through the fallopian tube. Reprod Biomed Online 2002; 4: 160-9.

50 Baillie HS, Pacey AA, Warren MA, Scudamore IW, Barratt CL. Greater numbers of human spermatozoa associate with endosalpingeal cells derived from the isthmus compared with those from the ampulla. Hum Reprod 1997; 12: 1985-92.

51 Murray SC, Smith TT. Sperm interaction with fallopian tube apical membran enhances sperm motility and delays capacitation. Fertil Steril 1997; 68: 351-7.

52 DeMott RP, Suarez SS. Hyperactivated sperm progress in the mouse oviduct. Biol Reprod 1992; 46: 779-85.

$53 \mathrm{Ho}$ HC, Suarez SS. Hyperactivation of mammalian spermatozoa: function and regulation. Reproduction 2001; 122: 519-26.

54 Hunter RH. Ovarian control of very low sperm/egg ratios at the commencement of mammalian fertilisation to avoid polyspermy. Mol Reprod Dev 1996; 44: 417-22.

55 Dobrinski I, Ignotz GG, Thomas PG, Ball BA. Role of carbohydrates in the attachment of equine spermatozoa to uterine tubal (oviductal) epithelial cells in vitro. Am J Vet Res 1996; 57: 1635-9.

56 Ignotz GG, Lo MC, Perez CL, Gwathmey TM, Suarez SS. Characterization of a fucosebinding protein from bull sperm and seminal plasma that may be responsible for formation of the oviductal sperm reservoir. Biol Reprod 2001; 64: 1806-11.

57 Ignotz GG, Cho MY, Suarez SS. Annexins are candidate oviductal receptors for bovine sperm surface proteins and thus may serve to hold bovine sperm in the oviductal reservoir. Biol Reprod 2007; 77: 906-13.

58 Lefebvre J, Fan J, Chevalier S, Sullivan R, Carmona E et al. Genomic structure and tissue-specific expression of human and mouse genes encoding homologues of the major bovine seminal plasma proteins. Mol Hum Reprod 2007; 13: 45-53.

59 Reeve L, Ledger WL, Pacey AA. Does the Arg-Gly-Asp (RGD) adhesion sequence play a role in mediating sperm interaction with the human endosalpinx? Hum Reprod 2003 18: $1461-8$.

60 Gualtieri R, Mollo V, Duma G, Talevi R. Redox control of surface protein sulphhydryls in bovine spermatozoa reversibly modulates sperm adhesion to the oviducta epithelium and capacitation. Reproduction 2009; 138: 33-43.

61 Gualtieri R, Mollo V, Barbato V, Talevi R. Ability of sulfated glycoconjugates and disulfide-reductants to release bovine epididymal sperm bound to the oviducta epithelium in vitro. Theriogenology 2010; 73: 1037-43.

62 Ellington JE, Evenson DP, Wright RW Jr, Jones AE, Schneider CS et al. Higher-quality human sperm in a sample selectively attach to oviduct (fallopian tube) epithelial cells in vitro. Fertil Steril 1999; 71: 924-9.

63 Bahat $A$, Eisenbach $M$. Human sperm thermotaxis is mediated by phospholipase $C$ and inositol trisphosphate receptor $\mathrm{Ca}^{2+}$ channel. Biol Reprod 2010; 82: 606-16.

64 Bahat A, Tur-Kaspa I, Gakamsky A. Thermotaxis of mammalian sperm cells: a potential navigation mechanism in the female genital tract. Nat Med 2003; 9 149-50.

65 Bahat A, Eisenbach M, Tur-Kaspa I. Periovulatory increase in temperature difference within the rabbit oviduct. Hum Reprod 2005; 20: 2118-21.

66 Eisenbach M. Sperm chemotaxis. Rev Reprod 1999; 4: 56-66.

67 Babcock DF. Development. Smelling the roses? Science 2003; 299: 1993-4.
68 Teves ME, Guidobaldi HA, Unates DR, Sanchez R, Miska W et al. Molecular mechanism for human sperm chemotaxis mediated by progesterone. PLoS One 2009; 4: e8211.

69 Miraglia E, Rullo ML, Bosia A, Massobrio M, Revelli A et al. Stimulation of the nitric oxide/cyclic guanosine monophosphate signaling pathway elicits human sperm chemotaxis in vitro. Fertil Steril 2007; 87: 1059-63.

70 Sanchez R, Sepulveda C, Risopatron J, Villegas J, Giojalas LC. Human sperm chemotaxis depends on critical levels of reactive oxygen species. Fertil Steril 2010; 93: 150-3.

71 Cohen-Dayag A, Tur-Kaspa I, Dor J, Mashiach S, Eisenbach M. Sperm capacitation in humans is transient and correlates with chemotactic responsiveness to follicular factors. Proc Natl Acad Sci USA 1995; 92: 11039-43.

72 Sun F, Bahat A, Gakamsky A, Girsh E, Katz N etal. Human sperm chemotaxis: both the oocyte and its surrounding cumulus cells secrete sperm chemoattractants. Hum Reprod 2005; 20: 761-7.

73 Seppälä M, Koistinen H, Koistinen R, Chiu PC, Yeung WS. Glycosylation related actions of glycodelin: gamete, cumulus cell, immune cell and clinical associations. Hum Reprod Update 2007; 13: 275-87.

74 Yeung WS, Lee KF, Koistinen R, Koistinen H, Seppälä M et al. Effects of glycodelins on functional competence of spermatozoa. J Reprod Immunol 2009; 83: 26-30.

75 Stauss CR, Votta TJ, Suarez SS. Sperm motility hyperactivation facilitates penetration of the hamster zona pellucida. Biol Reprod 1995; 53: 1280-5.

76 Quill TA, Sugden SA, Rossi KL, Doolittle LK, Hammer RE et al. Hyperactivated sperm motility driven by CatSper2 is required for fertilization. Proc Natl Acad Sci USA2003, 100: 14869-74.

77 Hong SJ, Chiu PC, Lee KF, Tse JY, Ho PC et al. Cumulus cells and their extracellular matrix affect the quality of the spermatozoa penetrating the cumulus mass. Fertil Steril 2009; 92: 971-8.

78 Russell DL, Salustri A. Extracellular matrix of the cumulus-oocyte complex. Sem Reprod Med 2006; 24: 217-27.

79 Kogan G, Soltes L, Stern R, Gemeiner P. Hyaluronic acid: a natural biopolymer with a broad range of biomedical and industrial applications. Biotechnol Lett 2007; 29: 17 25.

80 Chung MK, Chiu PC, Lee CL, Pang RT, Ng EH et al. Cumulus-associated $\alpha 2$ macroglobulin derivative retains proconceptive glycodelin- $\mathrm{C}$ in the human cumulus matrix. Hum Reprod 2009; 24: 2856-67.

81 Huszar G, Ozenci CC, Cayli S, Zavaczki Z, Hansch E et al. Hyaluronic acid binding by human sperm indicates cellular maturity, viability, and unreacted acrosomal status. Fertil Steril 2003; 79(Suppl 3): 1616-24.

82 Huszar G, Sbracia M, Vigue L, Miller DJ, Shur BD. Sperm plasma membrane remodeling during spermiogenetic maturation in men: relationship among plasma membrane beta 1,4-galactosyltransferase, cytoplasmic creatine phosphokinase, and creatine phosphokinase isoform ratios. Biol Reprod 1997; 56: 1020-4.

83 Ranganathan S, Ganguly AK, Datta K. Evidence for presence of hyaluronan binding protein on spermatozoa and its possible involvement in sperm function. Mol Reprod Dev 1994; 38: 69-76.

84 Hunnicutt GR, Primakoff P, Myles DG. Sperm surface protein PH-20 is bifunctional one activity is a hyaluronidase and a second, distinct activity is required in secondary sperm-zona binding. Biol Reprod 1996; 55: 80-6.

85 Sabeur K, Cherr GN, Yudin AI, Overstreet JW. Hyaluronic acid enhances induction of the acrosome reaction of human sperm through interaction with the $\mathrm{PH}-20$ protein. Zygote 1998; 6: 103-11.

86 Ghosh I, Chattopadhaya R, Kumar V, Chakravarty BN, Datta K. Hyaluronan binding protein-1: a modulator of sperm-oocyte interaction. Soc Reprod Fertil Supp/ 2007 63: 539-43.

87 Menkveld R, Franken DR, Kruger TF, Oehninger S, Hodgen GD. Sperm selection capacity of the human zona pellucida. Mol Reprod Dev 1991; 30: 346-52.

88 Liu DY, Baker HW. Morphology of spermatozoa bound to the zona pellucida of human oocytes that failed to fertilize in vitro. J Reprod Fertil 1992; 94: 71-84.

89 Liu DY, Baker HW. Human sperm bound to the zona pellucida have normal nuclear chromatin as assessed by acridine orange fluorescence. Hum Reprod 2007; 22 1597-602.

90 Menkveld R, El-Garem Y, Schill WB, Henkel R. Relationship between human sperm morphology and acrosomal function. J Assist Reprod Genet 2003; 20: 432-8.

91 Liu DY, Baker HW. Disordered zona pellucida-induced acrosome reaction and failure of in vitro fertilization in patients with unexplained infertility. Fertil Steril 2003; 79: 74-80.

92 Menkveld R, Stander FS, Kotze TJ, Kruger TF, van Zyl JA. The evaluation of morphological characteristics of human spermatozoa according to stricter criteria. Hum Reprod 1990; 5: 586-92.

93 Oehninger $\mathrm{S}$, Kruger $\mathrm{T}$. The diagnosis of male infertility by semen quality. Clinical significance of sperm morphology assessment. Hum Reprod 1995; 10: 1037-8.

94 Garolla A, Fortini D, Menegazzo M, de Toni L, Nicoletti V et al. High-power microscopy for selecting spermatozoa for ICSI by physiological status. Reprod Biomed Online 2008; 17: 610-6.

95 Avendano C, Franchi A, Taylor S, Morshedi M, Bocca S et al. Fragmentation of DNA in morphologically normal human spermatozoa. Fertil Steril 2009; 91: 1077-84.

96 Berkovitz A, Eltes F, Soffer Y, Zabludovsky N, Beyth Y et al. ART success and in vivo sperm cell selection depend on the ultramorphological status of spermatozoa. Andrologia 1999; 31: 1-8.

97 Wilding M, Coppola G, di Matteo L, Palagiano A, Fusco E et al. Intracytoplasmic injection of morphologically selected spermatozoa (IMSI) improves outcome after 
assisted reproduction by deselecting physiologically poor quality spermatozoa. J Assist Reprod Genet 2011; 28: 253-62.

98 Ryu HM, Lin WW, Lamb DJ, Chuang W, Lipshultz LI et al. Increased chromosome X, Y, and 18 nondisjunction in sperm from infertile patients that were identified as normal by strict morphology: implication for intracytoplasmic sperm injection. Fertil Steril 2001; 76: 879-83.

99 Aitken RJ, de luliis GN. Origins and consequences of DNA damage in male germ cells. Reprod Biomed Online 2007; 14: 727-33.

100 Bartoov B, Berkovitz A, Eltes F, Kogosowski A, Menezo Y et al. Real-time fine morphology of motile human sperm cells is associated with IVF-ICSI outcome. J Androl 2002; 23: 1-8.

101 Franco JG Jr, Mauri AL, Petersen CG, Massaro FC, Silva LF et al. Large nuclear vacuoles are indicative of abnormal chromatin packaging in human spermatozoa. Int J Androl; e-pub ahead of print 28 April 2011; doi:10.1111/j.1365-2605. 2011.01154.x.

102 Oliveira JB, Massaro FC, Mauri AL, Petersen CG, Nicoletti AP et al. Motile sperm organelle morphology examination is stricter than Tygerberg criteria. Reprod Biomed Online 2009; 18: 320-6.

103 Bartoov B, Berkovitz A, Eltes F, Kogosovsky A, Yagoda A et al. Pregnancy rates are higher with intracytoplasmic morphologically selected sperm injection than with conventional intracytoplasmic injection. Fertil Steril 2003; 80: 1413-9.

104 Hazout A, Dumont-Hassan M, Junca AM, Cohen Bacrie P, Tesarik J. Highmagnification ICSI overcomes paternal effect resistant to conventional ICSI. Reprod Biomed Online 2006; 12: 19-25.

105 Souza Setti A, Ferreira RC, Paes de Almeida Ferreira Braga D, de Cassia Savio Figueira $\mathrm{R}$, laconelli A Jr et al. Intracytoplasmic sperm injection outcome versus intracytoplasmic morphologically selected sperm injection outcome: a meta-analysis. Reprod Biomed Online 2010; 21: 450-5.

106 Balaban B, Yakin K, Alatas C, Oktem O, Isiklar A et al. Clinical outcome of intracytoplasmic injection of spermatozoa morphologically selected under high magnification: a prospective randomized study. Reprod Biomed Online e-pub ahead of print 15 February 2011; doi: 10.1016/j.rbmo.2010.11.003.

107 de Cassia Savio Figueira R, Braga DP, Setti AS, laconelli A Jr, Borges E Jr. Morphological nuclear integrity of sperm cells is associated with preimplantation genetic aneuploidy screening cycle outcomes. Fertil Steril 2011; 95: 990-3.

108 Mauri AL, Petersen CG, Oliveira JB, Massaro FC, Baruffi RL et al. Comparison of day 2 embryo quality after conventional ICSI versus intracytoplasmic morphologically selected sperm injection (IMSI) using sibling oocytes. Eur J Obstet Gynecol Reprod Biol 2010; 150: 42-6.

109 Vanderzwalmen P, Hiemer A, Rubner P, Bach M, Neyer A et al. Blastocyst development after sperm selection at high magnification is associated with size and number of nuclear vacuoles. Reprod Biomed Online 2008; 17: 617-27.

110 Ahmadi A, Ng SC. Developmental capacity of damaged spermatozoa. Hum Reprod 1999; 14: 2279-85.

111 Barroso G, Valdespin C, Vega E, Kershenovich R, Avila R et al. Developmental sperm contributions: fertilization and beyond. Fertil Steril 2009; 92: 835-48.

112 Tesarik J. Paternal effects on cell division in the human preimplantation embryo. Reprod Biomed Online 2005; 10: 370-5.

113 Berkovitz A, Eltes F, Yaari S, Katz N, Barr I et al. The morphological normalcy of the sperm nucleus and pregnancy rate of intracytoplasmic injection with morphologically selected sperm. Hum Reprod 2005; 20: 185-90.

114 Peer S, Eltes F, Berkovitz A, Yehuda R, Itsykson P et al. Is fine morphology of the human sperm nuclei affected by in vitro incubation at 37 degrees C? Fertil Steril 2007; 88: 1589-94.

115 Kirchhoff C, Schröter S. New insights into the origin, structure and role of CD52: a major component of the mammalian sperm glycocalyx. Cells Tissues Organs 2001; 168: 93-104.

116 Rooney IA, Heuser JE, Atkinson JP. GPI-anchored complement regulatory proteins in seminal plasma. An analysis of their physical condition and the mechanisms of their binding to exogenous cells. J Clin Invest 1996; 97: 1675-86.

117 Focarelli R, Rosati F, Terrana B. Sialyglycoconjugates release during in vitro capacitation of human spermatozoa. J Androl 1990; 11: 97-104.

118 Giuliani V, Pandolfi C, Santucci R, Pelliccione F, Macerola B et al. Expression of gp20, a human sperm antigen of epididymal origin, is reduced in spermatozoa from subfertile men. Mol Reprod Dev 2004; 69: 235-40.

119 Ishijima SA, Okuno M, Mohri H. Zeta potential of human X-and Y-bearing sperm. Int J Androl 1991; 14: 340-7.

120 Chan PJ, Jacobson JD, Corselli JU, Patton WC. A simple zeta method for sperm selection based on membrane charge. Fertil Steril 2006; 85: 481-6.

121 Razavi SH, Nasr-Esfahani MH, Deemeh MR, Shayesteh M, Tavalaee M. Evaluation of zeta and $\mathrm{HA}$-binding methods for selection of spermatozoa with normal morphology, protamine content and DNA integrity. Andrologia 2009; 42: 13-9.

122 Kam TL, Jacobson JD, Patton WC, Corselli JU, Chan PJ. Retention of membrane charge attributes by cryopreserved-thawed sperm and zeta selection. J Assist Reprod Genet 2007; 24: 429-34.

123 Kheirollahi-Kouhestani M, Razavi S, Tavalaee M, Deemeh MR, Mardani M et al. Selection of sperm based on combined density gradient and Zeta method may improve ICSI outcome. Hum Reprod 2009; 24: 2409-16.

124 Kaneko S, Oshio S, Kobayashi T, lizuka R, Mohri H. Human X- and Y-bearing sperm differ in cell surface sialic acid content. Biochem Biophys Res Commun 1984; 124 : 950-5.

125 Cartwright EJ, Harrington PM, Cowin A, Sharpe PT. Separation of bovine X and Y sperm based on surface differences. Mol Reprod Dev 1993; 34: 323-8.
126 Della Giovampaola C, Flori F, Sabatini L, Incerti L, La Sala GB et al. Surface of human sperm bears three differently charged CD52 forms, two of which remain stably bound to sperm after capacitation. Mol Reprod Dev 2001; 60: 89-96.

127 Ainsworth C, Nixon B, Aitken RJ. Development of a novel electrophoretic system for the isolation of human spermatozoa. Hum Reprod 2005; 20: 2261-70.

128 Ainsworth C, Nixon B, Jansen RP, Aitken RJ. First recorded pregnancy and normal birth after ICSI using electrophoretically isolated spermatozoa. Hum Reprod 2007; 22: 197-200.

129 Fleming SD, Ilad RS, Griffin AM, Wu Y, Ong KJ et al. Prospective controlled trial of an electrophoretic method of sperm preparation for assisted reproduction: comparison with density gradient centrifugation. Hum Reprod 2008; 23: 2646-51.

130 Aitken RJ, Hanson AR, Kuczera L. Electrophoretic sperm isolation: optimization of electrophoresis conditions and impact on oxidative stress. Hum Reprod 2011; 26: 1955-64.

131 Ainsworth CJ, Nixon B, Aitken RJ. The electrophoretic separation of spermatozoa: an analysis of genotype, surface carbohydrate composition and potential for capacitation. Int J Androl; e-pub ahead of print 12 May 2011; doi:10.1111/j.1365-2605. 2011.01164.x.

132 van Heerde WL, Degroot PG, Reutelingsperger CP. The complexity of the phospholipid binding protein annexin V. Thromb Haemost1995; 73: 172-9.

133 Vermes I, Haanen C, Reutelingsperger CP. A novel assay for apoptosis: flow cytometric detection of phosphatidylserine expression on early apoptotic cells using fluorescence labelled annexin V. J Immunol Methods 1995; 180: 39-52.

134 Sakkas D, Mariethoz E, St John JC. Abnormal sperm parameters in humans are indicative of an abortive apoptotic mechanism linked to the Fas-mediated pathway. Exp Cell Res 1999; 251: 350-5.

135 Gadella BM, Harrison RA. Capacitation induces cyclic adenosine 3', 5'monophosphate-dependent, but apoptosis-unrelated, exposure of aminophospholipids at the apical head plasma membrane of boar sperm cells. Biol Reprod 2002; 67: 340-50.

136 Muratori M, Maggi M, Spinelli S, Filimberti E, Forti G et al. Spontaneous DNA fragmentation in swim-up selected human spermatozoa during long term incubation. J Androl 2003; 24: 253-62.

137 Sun JG, Jurisicova A, Casper RF. Detection of deoxyribonucleic acid fragmentation in human sperm: correlation with fertilization in vitro. Biol Reprod 1997; 56: 602-7.

138 Barroso G, Taylor S, Morshedi M, Manzur F, Gavino F et al. Mitochondrial membrane potential integrity and plasma membrane translocation of phosphatidylserine as early apoptotic markers: a comparison of two different sperm subpopulations. Fertil Steril 2006; 85: 149-54

139 Grunewald S, Paasch U, Glander HJ. Enrichment of non-apoptotic human spermatozoa after cryopreservation by immunomagnetic cell sorting. Cell Tissue Bank 2001; 2: 127-33.

140 Glander HJ, Schiller J, Süß R, Paasch U, Grunewald S et al. Deterioration of spermatozoal plasma membrane is associated with an increase of sperm lysophosphatidylcholines. Andrologia 2002; 34: 360-6.

141 de Vantery Arrighi C, Lucas H, Chardonnens D, de Agostini A. Removal of spermatozoa with externalized phosphatidylserine from sperm preparation in human assisted medical procreation: effects on viability, motility and mitochondrial membrane potential. Reprod Biol Endocrinol 2009; 7: 1

142 Said TM, Grunewald S, Paasch U, Glander HJ, Baumann T et al. Advantage of combining magnetic cell separation with sperm preparation techniques. Reprod Biomed Online 2005; 10: 740-6.

143 Said T, Agarwal A, Grunewald S, Rasch M, Baumann T et al. Selection of nonapoptotic spermatozoa as a new tool for enhancing assisted reproduction outcomes: an in vitro model. Biol Reprod 2006; 74: 530-7.

144 Dirican EK, Ozgün OD, Akarsu S, Akin KO, Ercan 0 et al. Clinical outcome of magnetic activated cell sorting of non-apoptotic spermatozoa before density gradient centrifugation for assisted reproduction. J Assist Reprod Genet 2008; 25: 375-81.

145 Polak de Fried E, Denaday F. Single and twin ongoing pregnancies in two cases of previous ART failure after ICSI performed with sperm sorted using annexin V microbeads. Fertil Steril 2010; 94: 351.e15-8.

146 Rawe VY, Boudri HU, Alvarez Sedo C, Carro M, Papier S et al. Healthy baby born after reduction of sperm DNA fragmentation using cell sorting before ICSI. Reprod Biomed Online 2010; 20: 320-3.

147 Grunewald S, Miska W, Miska G, Rasch M, Reinhardt M et al. Molecular glass wool filtration as a new tool for sperm preparation. Hum Reprod 2007; 22: 1405-12.

148 Hoogendijk CF, Kruger TF, Bouic PJ, Henkel RR. A novel approach for the selection of human sperm using annexin V-binding and flow cytometry. Fertil Steril 2009; 91 : 1285-92.

149 Huszar G. Willetts M. Corrales M. Hyaluronic acid (Sperm Select) improves retention of sperm motility and velocity in normozoospermic and oligozoospermic specimens. Fertil Steril 1990; 54: 1127-34

150 Slotte $\mathrm{H}$, Akerlof $\mathrm{E}$, Pousette A. Separation of human spermatozoa with hyaluronic acid induces, and Percoll inhibits, the acrosome reaction. Int J Androl 1993; 16: 349-54.

151 Huszar G, Jakab A, Sakkas D, Ozenci CC, Cayli S et al. Fertility testing and ICSI sperm selection by hyaluronic acid binding: clinical and genetic aspects. Reprod Biomed Online 2007; 14: 650-63.

152 Jakab A, Sakkas D, Delpiano E, Cayli S, Kovanci E et al. Intracytoplasmic sperm injection: a novel selection method for sperm with normal frequency of chromosomal aneuploidies. Fertil Steril 2005; 84: 1665-73. 
153 Nasr-Esfahani MH, Razavi S, Vahdati AA, Fathi F, Tavalaee M. Evaluation of sperm selection procedure based on hyaluronic acid binding ability on ICSI outcome. J Assist Reprod Genet 2008; 25: 197-03.

154 Parmegiani L, Cognigni GE, Bernardi S, Troilo E, Ciampaglia W et al. "Physiologic ICSI": hyaluronic acid (HA) favors selection of spermatozoa without DNA fragmentation and with normal nucleus, resulting in improvement of embryo quality. Fertil Steril 2010; 93: 598-604.

155 Yagci A, Murk W, Stronk J, Huszar G. Spermatozoa bound to solid state hyaluronic acid show chromatin structure with high DNA chain integrity: an acridine orange fluorescence study. J Androl 2010; 31: 566-72.

156 van den Bergh MJ, Fahy-Deshe M, Hohl MK. Pronuclear zygote score following intracytoplasmic injection of hyaluronan-bound spermatozoa: a prospective randomized study. Reprod Biomed Online 2009; 19: 796-801.

157 Parmegiani L, Cognigni GE, Filicori M. Risks in injecting hyaluronic acid non-bound spermatozoa. Reprod Biomed Online 2010; 20: 437-8.

158 Ye H, Huang GN, Gao Y, Liu DY. Relationship between human sperm-hyaluronan binding assay and fertilization rate in conventional in vitro fertilization. Hum Reprod 2006; 21 : 1545-50.

159 Nijs M, Creemers E, Cox A, Franssen K, Janssen M et al. Chromomycin A3 staining, sperm chromatin structure assay and hyaluronic acid binding assay as predictors for assisted reproductive outcome. Reprod Biomed Online 2009; 19: 671-84.

160 Petersen CG, Massaro FC, Mauri AL, Oliveira JB, Baruffi RL et al. Efficacy of hyaluronic acid binding assay in selecting motile spermatozoa with norma morphology at high magnification. Reprod Biol Endocrinol .2010; 8: 149.

161 Nijs M, Creemers E, Cox A, Janssen M, Vanheusden E et al. Relationship between hyaluronic acid binding assay and outcome in ART: a pilot study. Andrologia 2010; 42: 291-6.

162 Paes Almeida Ferreira de Braga D, laconelli A Jr, Cassia Savio de Figueira R, Madasch C, Semiao-Francisco L et al. Outcome of ICSI using zona pellucida-bound spermatozoa and conventionally selected spermatozoa. Reprod Biomed Online 2009; 19: 802-7.

163 Black M, Liu DY, Bourne H, Baker HW. Comparison of outcomes of conventional intracytoplasmic sperm injection and intracytoplasmic sperm injection using sperm bound to the zona pellucida of immature oocytes. Fertil Steril 2010; 93: 672-4.

164 Liu F, Qiu Y, Zou Y, Deng ZH, Yang H et al. Use of zona pellucida-bound sperm for intracytoplasmic sperm injection produces higher embryo quality and implantation than conventional intracytoplasmic sperm injection. Fertil Steril 2011; 95: 815-8

165 Franken DR, Bastiaan HS. Can a cumulus cell complex be used to select spermatozo for assisted reproduction? Andrologia 2009; 41: 369-76.
166 Krishna CM, Sockalingum GD, Kurien J, Rao L, Venteo L et al. Micro-Raman spectroscopy for optical pathology of oral squamous cell carcinoma. App/ Spectrosc 2004; 58: 1128-35.

167 Chowdary MV, Kumar KK, Kurien J, Mathew S, Krishna CM. Discrimination of normal, benign and malignant breast tissues by Raman spectroscopy. Biopolymers 2006; 83 556-69.

168 Vidyasagar MS, Maheedhar K, Vadhiraja BM, Fernendes DJ, Kartha VB et al. Prediction of radiotherapy response in cervix cancer by Raman spectroscopy: a pilot study. Biopolymers 2008; 89: 530-7.

169 Downes A, Mouras R, Elfick A. Optical spectroscopy for noninvasive monitoring of stem cell differentiation. J Biomed Biotechnol 2010; 2010: 101864

170 Huser T, Orme CA, Hollars CW, Corzett MH, Balhorn R. Raman spectroscopy of DNA packaging in individual human sperm cells distinguishes normal from abnormal cells. J Biophotonics 2009; 2: 322-32.

171 Itzkan I, Qiu L, Fang H, Zaman MM, Vitkin E et al. Confocal light absorption and scattering spectroscopic microscopy monitors organelles in live cells with no exogenous labels. Proc Natl Acad Sci USA 2007; 104: 17255-60.

172 Schuele G, Vitkin E, Huie P, Palanker D, Perelman LT. Optical spectroscopy noninvasively monitors response of organelles to cellular stress. J Biomed Opt 2005; 10: 051404.

173 Baccetti B. Microscopical advances in assisted reproduction. J Submicrosc Cyto Pathol 2004; 36: 333-9.

174 Gianaroli L, Magli MC, Ferraretti AP, Crippa A, Lappi M et al. Birefringence characteristics in sperm heads allow for the selection of reacted spermatozoa for intracytoplasmic sperm injection. Fertil Steril 2010; 93: 807-13.

175 Gianaroli L, Magli MC, Collodel G, Moretti E, Ferraretti AP et al. Sperm head's birefringence: a new criterion for sperm selection. Fertil Steril 2008; 90: 104-12.

176 Petersen CG, Vagnini LD, Mauri AL, Massaro FC, Cavagna M et al. Relationship between DNA damage and sperm head birefringence. Reprod Biomed Online 2011; 22: 583-9.

177 Crippa A, Magli MC, Paviglianiti B, Boudjema E, Ferraretti AP et al. DNA fragmentation and characteristics of birefringence in human sperm head. Hum Reprod 2009; 24(Suppl 1): i95.

178 Vagnini LD, Petersen CG, Mauri AL, Massaro FC, Junta CM et al. Can sperm-head birefringence indicate sperm chromatin-packaging abnormalities? Hum Reprod .2010; 25(Suppl 1): i279.

179 Gianaroli L, Magli MC, Ferraretti AP, Crippa A, Lappi M et al. Birefringence characteristics in sperm heads allow for the selection of reacted spermatozoa for intracytoplasmic sperm injection. Fertil Steril 2010; 93: 807-13.

180 Kaupp UB, Kashikar ND, Weyand I. Mechanisms of sperm chemotaxis. Annu Rev Physiol 2008; 70: 93-117. 